\title{
MILK QUANTITY, COMPOSITION AND HYGIENE TRAITS OF ROUTINELY MACHINE MILKED LIPIZZAN MARES
}

\author{
Ana Kaić ${ }^{1}$, Barbara Luštrek ${ }^{2 *}$, Mojca Simčič ${ }^{2}$, Klemen Potočnik $^{2}$ \\ 1University of Zagreb, Faculty of Agriculture, Department of Animal Science and Technology, Svetošimunska cesta 25, 10000 Zagreb, \\ Croatia, ${ }^{2}$ University of Ljubljana, Biotechnical Faculty, Department of Animal Science, Groblje 3, SI-1230 Domžale, Slovenia
}

${ }^{*}$ Corresponding author, E-mail: barbara.lustrek@bf.uni-lj.si

\begin{abstract}
The aim of the study was to research milk yield, composition and hygienic quality of routinely produced milk from Lipizzan mares. It was the first known case of adapting mares of this breed to the routine machine milking procedure. Three Lipizzan mares included in the routine machine milking produced commercial quantities of mare's milk.

Milk from Lipizzan horse breed was for the first time obtained and analysed in such quantity. The mares were milked consecutively three times per day during five days in a week, and during weekends, they were joined with their foals. The average values were as follows: daily milk yield (MY) was $8.24 \mathrm{~kg}$, fat content (FC) was $4.027 \mathrm{~g} / \mathrm{kg}$, protein content (PC) was $15.064 \mathrm{~g} / \mathrm{kg}$, lactose content (LC) was $63.218 \mathrm{~g} / \mathrm{kg}$, somatic cell count (SCC) was $6.556 \times 10^{3} / \mathrm{ml}$, total bacteria count (TBC) was $114.689 \times 10^{3} / \mathrm{ml}$, and average freezing point (FP) was $-0.505^{\circ} \mathrm{C}$. Consecutive milking significantly influenced PC, LC, SCC, and TBC. FC tended to increase with days in milk, whereas PC, SCC, and TBC decreased during the lactation stage. Significant differences between mares were found in PC, LC, SSC and TBC. Interaction between consecutive milking and mare was significant only for FC. The study confirmed that warmblooded horse breed can be used for commercial milk production along with coldblooded breeds. Routine machine milk production with use of Lipizzan mares could add an economic value to the indigenous breed and serve as an additional reason for its preservation.
\end{abstract}

Key words: milk composition; milkyield; days in milk; consecutive milking; hygienic quality

\section{Introduction}

The Lipizzan horse, established in $16^{\text {th }}$ century in Lipica, Slovenia, is Slovenian indigenous breed and one of the oldest cultured horse breeds in the world. It is mainly used as a riding horse for leisure, sport dressage, classical dressage, and for carriage driving. According to Lipizzan International Federation, the majority of the Lipizzan population is bred by the private breeders in 19 countries and on nine state studs in the Central and Eastern Europe. Successful long-term

Received: 30 October 2018

Accepted for publication: 4 June 2019 preservation of indigenous horse breeds could only be performed by their economic utilization. According to Potočnik (1) the preservation with an economic increase of equine breeding could be achieved by milk production and its processing. There has been an increasing interest on the use of mare's milk in human nutrition, cosmetic and pharmaceutical industry in the recent years (2). Because of its nutritional characteristics, mare's milk is used as a low-allergenic substitute for bovine milk (3), as a substitute for human and bovine milk for premature new-borns (4) and as a healing agent for several diseases and disorders (5). It has been reported that use of mare's milk acts beneficially against skin diseases, supports 
general physical health, immune system and stomach function, keeps vitality of muscles, joints and bones, and aids with metabolism problems, liver diseases, cardiovascular diseases and cancer (2). Fat component of mare's milk is considered as a valuable ingredient in the cosmetics due to its high polyunsaturated fatty acids content, while proteins are used as an active component for skin hydration and prevention of skin ageing (6).

Production, composition and hygienic quality of milk may change depending on the lactation stage, age, parity and milk management $(7,8)$. Many studies investigated and reviewed some of these factors and their influence on the production of mare's milk (e.g. 8, 9, 10, 11). However, there is still a lack of knowledge regarding this topic. Hygienic status of mare's milk is most commonly described by somatic cell count and information on total bacteria count is difficult to find (8). Published data originates mostly from milk samples taken from mares that were not included in a routine milk production. Such samples in majority represent only first jets of milk and cannot equate with the quality of milk samples from completely milked udder.

This study was undertaken to examine the routinely produced milk from Lipizzan mares and it was the first known case of adapting mares of this breed to the routine machine milking procedure. Milk yield, composition and hygienic quality of milk were researched.

\section{Material and methods}

\section{Animals and management}

The experiment was carried out at the Equine Education and Research Centre Krumperk (EERC) of Department of Animal Science at Biotechnical Faculty, University of Ljubljana, Slovenia. From May 2011 on, EERC was the first registered establishment for raw mare's milk production and ethics approval was not required for the study. Milk samples were collected from three Lipizzan mares (Famosa XI, Thais VII and Bistrica IV) aged seven years. Two of them were in the second parity, and one was in the third parity. The body weight of the mares in the experiment was estimated using chest girth measurement (12). The chest girth measurement of Famosa XI and Bistrica IV was $187 \mathrm{~cm}$ and their estimated body weight (BW) was $516 \mathrm{~kg}$, whereas the chest girth measurement of the Thais VII was $199 \mathrm{~cm}$ and her estimated BW was $607 \mathrm{~kg}$. All mares were fed with the same feed; their diet consisted of 12 $\mathrm{kg}$ of first cut hay mid quality, $800 \mathrm{~g}$ beet pulp, $1500 \mathrm{~g}$ oats, $2200 \mathrm{~g}$ feed mixture $(2871 \mathrm{kcal} / \mathrm{kg}$, $14 \%$ crude protein), $300 \mathrm{~g}$ wheat bran, and $50 \mathrm{~g}$ mineral-vitamin mixture. Mares were adapted to the routine machine milking before the start of experiment. They were milked consecutively three times per day during five days in a week, and during weekends they were joined with their foals. Mares foaled from March to April and the routine milking started at the end of their second month of lactation. Milk samples for the analyses were taken from mid-August to the end of September.

\section{Milk sampling}

Milking was carried out by a Milkline milking machine for goats (model Economy $1 \mathrm{E}$ ) adapted to the mares, with a mean vacuum level of $42 \mathrm{kPa}$, a pulsation rate of 120 cycles/min, and a pulsation ratio $1: 1$. Before the start of milking routine $(3 \mathrm{~h}$ before first milking) foals were separated from the mares with the fences, which allowed nasal and visual contact with mares. Mares were milked three times per day, always at the same time. Separation was carried out at 07:30 a.m., first milking started at 10:30 a.m., second at 01:30 p.m., and third milking at 04:30 p.m. After the third milking, foals were re-joined with the mares. Milk yield (MY) and composition were noted for each mare after each milking on each test day (TD) during five weeks of the trial. The average daily MY was expressed as an estimated daily milk synthesis in the mare's udder. The milk from completely milked udder was sampled for the first time on the TD for each mare at the $113^{\text {th }}$, $161^{\text {st }}$ and $157^{\text {th }}$ day of lactation $\left(1^{\text {st }}\right.$ week of trial). Samples were cooled and stored at $4^{\circ} \mathrm{C}$ till the next morning when the analysis was performed. Sampling was carried out in the 7-day intervals (once per week) until the end of the experiment. Altogether 45 representative samples (15 samples per mare) were analysed for contents of fat (FC), protein (PC), lactose (LC) as well as somatic cell count (SCC), total bacteria count (TBC) and freezing point (FP). 


\section{Analysis of milk}

Samples were analysed at the accredited laboratory of the Institute of Dairy Science at Biotechnical Faculty (University of Ljubljana, Slovenia). FC, PC and LC were determined using a mid-infrared spectrometer Milkoscan FT 6000 (Foss Electric, Hillerød, Denmark) according to the reference standard ISO-IDF 9622 (13). Freezing point was determined using a mid-infrared spectrometer Milkoscan FT 6000 equipped with Integrated Milk Testing (IMT) software. TBC was determined with Bactoscan FC 65+ (Foss Electric, Hillerød, Denmark) according to the reference standard ISO-IDF 21187 (14). SSC was determined with a fluoroopto-electronic counter Fossomatic 500 (Foss Electric, Hillerød, Denmark) in accordance with the reference standard ISOIDF 13366-2 (15).

\section{Statistical analysis}

Data were analysed by statistical package SAS/STAT (16). Mixed procedure was used for the analysis of variance. Statistical model was as follows:

$$
y_{i j k}=\mu+\beta\left(x_{i j k}-\bar{x}\right)+A_{i}+M_{j}+A M_{i j}+e_{i j k}
$$

and described overall mean $(\mu)$, mare $\left(A_{i}\right)$, consecutive milking $\left(M_{j}\right)$ and their interaction $\left(\mathrm{AM}_{\mathrm{ij}}\right)$ as fixed effects, days in milk $\left(\mathrm{x}_{\mathrm{ijk}}\right)$ as linear regression and random residual $\left(\mathrm{e}_{\mathrm{ijk}}\right)$. Differences (determined at $\mathrm{a}=0.05$ ) between least square means (LSM) were estimated using Bonferroni multiple comparison test. Average stage of lactation in the experiment was 151 days $(\bar{x})$.
The analysis of variance for SCC and TBC was performed using this values as logarithms $\left(\log _{2}\right.$ for SCC and $\log _{10}$ for TBC), while they were discussed as antilogarithms. The traits included in the model are presented as least square mean values with standard errors ( $\mathrm{LSM} \pm \mathrm{SE})$ and are shown at the following figures only when they were significantly different.

\section{Results}

The results for milk yield, chemical composition and hygienic quality of Lipizzan mare's milk are shown in Table 1 . The average estimated daily milk yield was $8.24 \mathrm{~kg}$, with a minimum of $5.44 \mathrm{~kg}$ and a maximum of $10.56 \mathrm{~kg}$. The milk production was $1.52 \mathrm{~kg} / 100 \mathrm{~kg}$ of BW.

Among milk composition traits, FC was the most variable trait with a coefficient of variation (CV) $73.39 \%$. The average FC was $4.0 \mathrm{~g} / \mathrm{kg}$, the average $\mathrm{PC}$ was $15.1 \mathrm{~g} / \mathrm{kg}$, whereas the average LC was $63.2 \mathrm{~g} / \mathrm{kg}$.

Hygienic status of mare's milk was evaluated throughout SCC and TBC. The mean values for SCC were generally low $\left(6.55 \times 10^{3} / \mathrm{ml}\right)$, with the minimum of $2.000 \times 10^{3} / \mathrm{ml}$ and maximum of 17.0 $\mathrm{x} 10^{3} / \mathrm{ml}$. Contrary to that, it was found that the average TBC in milk of Lipizzan mares was high $\left(114.69 \times 10^{3} / \mathrm{ml}\right)$. Coefficient of variation for the TBC in mare's milk was higher (127.01\%) than for the SCC (48.74\%). The mean value for FP was $-0.505{ }^{\circ} \mathrm{C}$, ranging from $-0.528{ }^{\circ} \mathrm{C}$ to $-0.443{ }^{\circ} \mathrm{C}$.

The present study indicated that consecutive milking (Figure 1) significantly influenced PC, LC, TBC, and FP. PC significantly differed $(P \leq 0.001)$ between consecutive milking: $1.52 \%$ in the milk from the first milking, $1.56 \%$ in the milk from the

Table 1: Milk yield, chemical composition and hygienic quality of Lipizzan mare's milk

\begin{tabular}{lccccc}
\hline Trait & Mean & SD & CV $(\%)$ & Minimum & Maximum \\
\hline Milk yield $(\mathrm{kg})$ & 8.24 & 1.87 & 22.69 & 5.44 & 10.56 \\
\hline Milk yield $(\mathrm{kg} / 100 \mathrm{~kg} \mathrm{BW})$ & 1.519 & 0.368 & 24.22 & 0.929 & 2.039 \\
\hline Fat content $(\mathrm{g} / \mathrm{kg})$ & 4.027 & 2.955 & 73.39 & 0.300 & 12.800 \\
\hline Protein content $(\mathrm{g} / \mathrm{kg})$ & 15.064 & 1.062 & 7.05 & 12.500 & 17.100 \\
\hline Lactose content $(\mathrm{g} / \mathrm{kg})$ & 63.218 & 2.137 & 3.38 & 57.600 & 66.100 \\
\hline SCC $\left(10^{3} / \mathrm{ml}\right)$ & 6.556 & 3.195 & 48.74 & 2.000 & 17.00 \\
\hline TBC $\left(10^{3} / \mathrm{ml}\right)$ & 114.689 & 145.667 & 127.01 & 7.0000 & 650.000 \\
\hline Freezing point $\left({ }^{\circ} \mathrm{C}\right)$ & -0.505 & 0.020 & 3.97 & -0.528 & -0.443 \\
\hline
\end{tabular}

SD: standard deviation; CV: coefficient of variation; SCC: somatic cell count; TBC: total bacteria count 

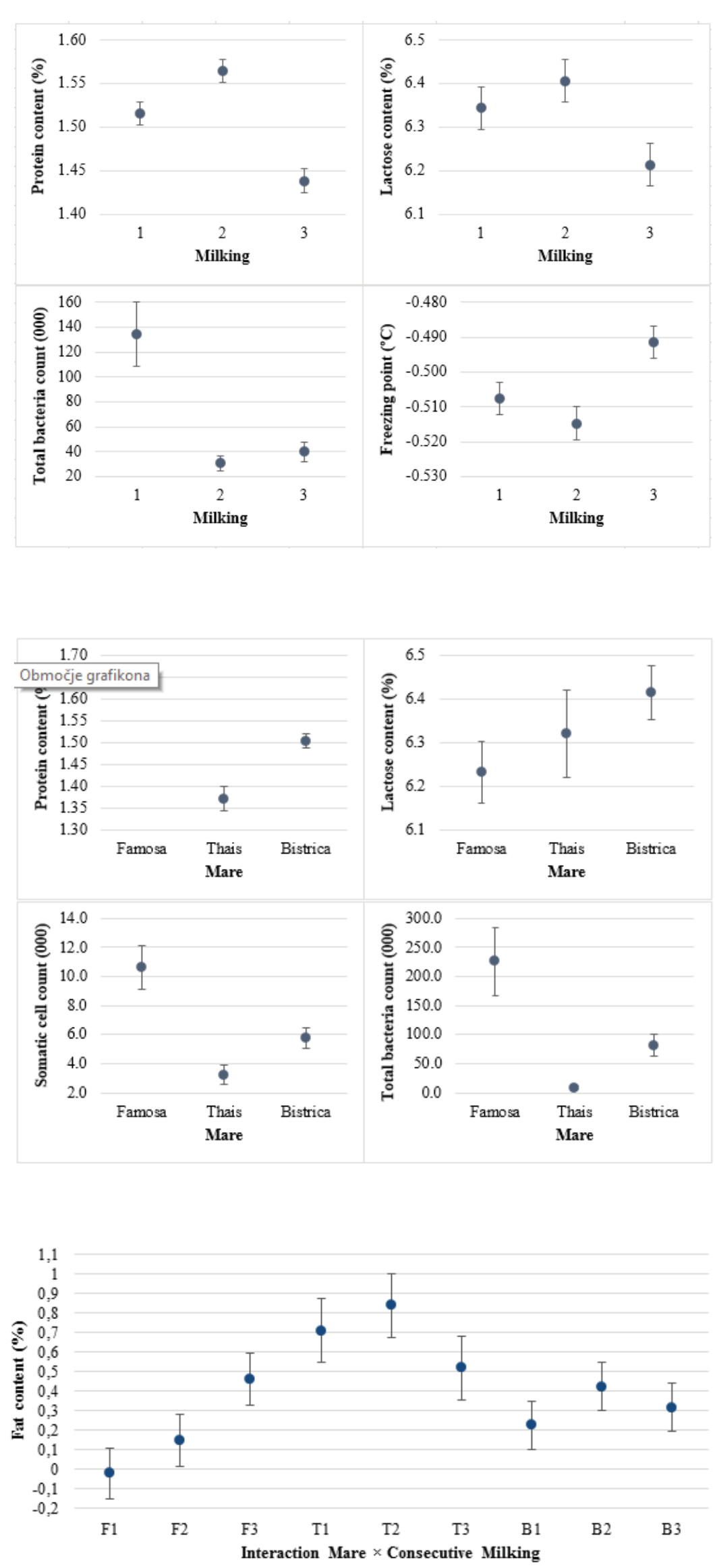

Figure 1: Influence of consecutive milking on protein content $(\%)$, lactose content $(\%)$, TBC $\left(10^{3} / \mathrm{ml}\right)$, and freezing point $\left({ }^{\circ} \mathrm{C}\right)$ in mare's milk
Figure 2: Influence of mare (Famosa, Thais, and Bistrica) on protein content $(\%)$, lactose content $(\%), \operatorname{SCC}\left(10^{3} / \mathrm{ml}\right)$, and TBC $\left(10^{3} / \mathrm{ml}\right)$ in mare's milk
Figure 3: Interaction between mare ( $\mathrm{F}=$ Famosa; $\mathrm{T}=$ Thais; $\mathrm{B}=$ =Bistrica) and consecutive milking (first $=1$, second $=2$, and third $=3$ ) on fat content (least square mean \pm standard error) in mare's milk 
second milking, and $1.44 \%$ in the milk from in the third milking. LC was significantly higher $(P$ $=0.026)$ in the samples from the second milking $(6.41 \%)$ compared to the ones from the third $(6.21 \%)$ milking. The highest TBC was found in the samples from first milking $\left(134.37 \times 10^{3} / \mathrm{ml}\right)$ and it significantly differed $(P \leq 0.001)$ from the content of samples from the second $\left(30.63 \times 10^{3} /\right.$ $\mathrm{ml})$ and the third $\left(39.96 \times 10^{3} / \mathrm{ml}\right)$ milking. The lowest FP of mare's milk was found in the second milking $\left(-0.515{ }^{\circ} \mathrm{C}\right)$.

The regression coefficient indicated that $\mathrm{FC}$ tended to increase during lactation stage, whereas PC, SCC, and TBC decreased. Results of this study, as well confirmed that PC of mare's milk would slowly decrease during lactation. By expectation $\mathrm{PC}$ would decrease for $0.01 \%$ in average with every additional day in milk. For every additional day in milk, SCC and TBC would decrease for 0.09 and $8.58 \times 10^{3} / \mathrm{ml}$ in average, meaning that hygienic quality of mare's milk during the lactation would slowly increase.

The results showed individual differences between mares' milk in PC, LC, SSC and TBC (Figure 2). PC significantly differed $(P \leq 0.001)$ between all mares. Thais VII had the lowest PC $(1.37 \%)$, whereas Bistrica IV (1.50\%) and Famosa XI (1.65\%) had higher PC in milk. LC was significantly higher $(P=0.040)$ in milk from Bistrica IV (6.41\%) than in milk from Famosa XI $(6.23 \%)$. The highest SCC was found in milk from Famosa XI $\left(10.60 \times 10^{3} / \mathrm{ml}\right)$, and it significantly differed $(P=0.001)$ from the SCC found in milk from Thais VII $\left(3.24 \times 10^{3} / \mathrm{ml}\right)$ and Bistrica IV $\left(5.75 \times 10^{3} / \mathrm{ml}\right)$. TBC also significantly differed $(P \leq$ 0.001 ) between all mares included in the study. It was found that Thais VII had the lowest TBC $(9.00$ x $\left.10^{3} / \mathrm{ml}\right)$, whereas Bistrica IV $\left(81.04 \times 10^{3} / \mathrm{ml}\right)$ and Famosa XI $\left(225.31 \times 10^{3} / \mathrm{ml}\right)$ had the highest TBC in milk. Among all analysed traits significant interaction between consecutive milking and mare was found only in FC $(P=0.038)$ (Figure 3).

\section{Discussion}

Compared to our results, Caroprese et al. (9) reported slightly lower daily milk yield $(7.69 \mathrm{~kg})$ from the machine milked light Murgese mares (average live weight of $550 \mathrm{~kg}$ ). However, it should be considered that Murgese mares were previously not subjected to any milking procedures.
According to Caroprese et al. (9) participation of untrained horses and milkmen resulted in a lower milk yield. Consequently, the adaptation to milking routine plays a crucial role in an optimal milk extraction. It is premised that the production of mare's milk is proportional to the mare's BW (2-3.5 kg milk/100 kg of BW) for sustainment of the rapid growth of the foal $(17,18)$. Similar data on the milk production, confirming the range from $2 \mathrm{~kg}$ to $3.5 \mathrm{~kg}$ of milk / $100 \mathrm{~kg}$ of BW, were reported for heavy mares by many authors $(4,19$, $20,21)$. The milk production in the present study, on the contrary, was slightly lower $(1.52 \mathrm{~kg} / 100$ $\mathrm{kg}$ of BW). Since the Lipizzan horse is a light, early matured breed with more narrow growth curve (BW can increase significantly even after 2 years of age), these lower values were somehow reasonable.

The average FC was lower than reported by Santos and Silvestre (21) for Lusitano mares (5.9 $\mathrm{g} / \mathrm{kg}$ ) and Centoducati et al. (4) for Italian Draft mares $(11.07 \mathrm{~g} / \mathrm{kg})$. Until now, there were no evidenced data on the milk traits of Lipizzan mares, so the lower FC could be characterised to the breed. In addition, Caroprese et al. (9) investigated milk production in hand and machine-milked Murgese mares and reported significant difference of the FC. They found higher FC (1.63\%) in samples from machine milked mares compared to the hand milked ones $(1.06 \%)$ due to more thorough emptying of udder and milk extraction from alveoli and galactophorous ducts. Regardless the fact that mares in this study were completely adapted to the routine machine milking, another explanation of a low FC and its high CV could be due to the insufficient oxytocin release during the machine milking. The average PC was lower than reported by Oftedal et al. (22) for Thoroughbred and Standardbred mares $(20.0 \mathrm{~g} / \mathrm{kg})$ or Santos and Silvestre (21) for Lusitano mares $(18.4 \mathrm{~g} / \mathrm{kg})$, and similar to the one reported by Centoducati et al. (4) for Italian Heavy Draft mares $(15.5 \mathrm{~g} / \mathrm{kg})$. Due to the higher content of lactose, mare's milk is considered to be much sweeter than the other types of milk used for human consumption. In the present study, the average LC was slightly higher than LC reported by Smolders et al. (23) for light mares $(62.0 \mathrm{~g} / \mathrm{kg})$ and Santos and Silvestre (21) for Lusitano mares $(60.8 \mathrm{~g} / \mathrm{kg})$.

Hygienic status of mare's milk was evaluated throughout SCC and TBC. Compared to the other species $(24,25,26)$ it could be confirmed that 
milk of Lipizzan mares had very low SCC. The mean values for SCC were lower than reported by Centoducati et al. (4) in milk of Italian Heavy Draft mares $\left(14.5 \times 10^{3} / \mathrm{ml}\right)$, Čagalj et al. (27) in milk of Croatian Cold Blooded mares $\left(22.5 \times 10^{3} / \mathrm{ml}\right)$, and higher than the ones evidenced by MarkiewiczKęszycka et al. (8) in Polish Cold Blooded mares $\left(3.5 \times 10^{3} / \mathrm{ml}\right)$. It is considered that mares have a generally good health status of the mammary gland and good microbial quality of milk due to the low volume of mare's udder, high resistance to pathogens, and high concentrations of lactoferrin, lysozyme and immunoglobulin in milk (8). Evaluation of the hygienic status of milk reported by Markiewicz-Kęszycka et al. (8) in Polish Cold Blooded horse (maximum of $72.0 \times 10^{3} / \mathrm{ml}$ ) and Čagalj et al. (27) in Croatian Cold Blooded horse (maximum of $58.0 \times 10^{3} / \mathrm{ml}$ ) confirmed that mares have a very low content of TBC. Contrary to that, it was found that the average TBC in milk of Lipizzan mares was high. Coefficient of variation for the TBC in mare's milk was higher than for the SCC. It is possible that this result is due to the inadequate hygiene measures taken during milking.

FP of milk is directly related to the concentration of water-soluble substance, from which the main effect on FP arises from lactose and minerals. The mean value for FP was similar to the previously reported mean value for FP $\left(-0.49{ }^{\circ} \mathrm{C}\right)$ in milk of Polish Cold Blooded horse with minimum and maximum values ranging from $-0.55{ }^{\circ} \mathrm{C}$ to $-0.47{ }^{\circ} \mathrm{C}(8)$.

MY in mares depends on and increases with the time elapsed between the last suckling of foal and milking (28). It has been pointed out that daily oscillation in the levels of physiological variables has been under influence of many factors (e.g. locomotor activity, body temperature, heart rate, blood pressure, hormonal and urinary secretion) so milk composition would also be expected to exhibit daily variation $(29,30)$. The present study indicated that $\mathrm{PC}, \mathrm{LC}, \mathrm{TBC}$, and FP were significantly influenced by consecutive milking. Although the major mare's milk constituents were not investigated during the whole day-night cycle as in the study of Piccione et al. (31) who researched daily rhythmicity of concentration of major constituents of asinine milk, peaks of PC were observed at similar time during the day, that is around 01:30 p.m..-However, contrary to our results, Piccione et al. (31) reported peak in LC during the night.
The highest TBC was found in the samples from the first milking and it significantly differed from the content of samples from the second and the third milking. Contrary to that, Piccione et al. (31) observed no daily rhythmicity of TBC in asinine milk. The lowest FP of mare's milk was found in the second milking. Since the mare's milk lower FP is directly connected to its higher LC (27) it was somehow expected that the higher LC in the second milking would affect the FP.

Although it is known that FC in milk is highly variable, the general trend based on literature data is an inverse function of lactation stage (32). Observed changes in the FC of Lipizzan mare's milk are contradicted to those in literature (17, $33,34)$. Namely, it could be expected that with each additional day in lactation, FC in mare's milk would increase by an average of $0.01 \%$. This might be attributed to the machine milking which, compared to hand milking results in milk with higher FC (9). Several authors confirmed that PC of mare's milk is influenced by the stage of lactation as it decreases over the lactating period $(17,21,33,34)$.

The results showed that every additional day in milk SCC and TBC would decrease meaning that hygienic quality of mare's milk during the lactation would slowly increase. Danków et al. (35) reported similar trend in Wielkopolska mare's milk for SCC and TBC measured from the first day of lactation (194 x 10 $/ \mathrm{cm}^{3}$ for SCC and $46 \times 10^{3} /$ $\mathrm{cm}^{3}$ for TBC) up to the $150^{\text {th }}$ day of lactation (41 $\mathrm{x}$ $10^{3} / \mathrm{cm}^{3}$ for SCC and $37 \times 10^{3} / \mathrm{cm}^{3}$ for TBC).

Among the factors associated with changes in the mare's milk composition, the effect of individual animal has been scarcely investigated. Mare significantly affected MY, FC, and PC in Slovenian draft horse, whereas consecutive milking affected only PC and FC (36). Our study also confirmed individual differences between Lipizzan mares in PC, LC, SSC and TBC. Doreau et al. (37) and Csapó et al. (38) reported low and insignificant inter-animal variation in mare's milk components. However, Doreau et al. (37) indicated that the individual differences among milk composition traits could be related to the udder characteristics or to requirements of the offspring (as in lactating cows), although no evidence was found to support this theory. 


\section{Conclusions}

This study provided information on milk yield, composition and hygienic quality of milk produced by Lipizzan mares that were included in the routine machine milking process carried on an establishment registered for raw mare's milk production. This was the first time that commercial quantities of milk from Lipizzan horse breed were obtained and analysed. The study confirmed that warmblooded horse breed can also be used for commercial milk production along with coldblooded breeds, and thus enabled future comparison. Fat content showed to be the most variable milk component while overall low somatic cell count indicated high hygienic quality of mare's milk. Analysis revealed that consecutive milking, stage of lactation, individual animal, and interaction between mare and consecutive milking affect the milk traits. Results indicated that routinely machine milked Lipizzan mares are suitable for commercial milk production. (Routine) milking would represent another way of economically justified use and additional reason for preservation of this indigenous horse breed. However, the need for in-depth knowledge on sustainable milk production system and conduction of a milking experiment with larger number of Lipizzan mares to provide an agreement and/or new insights with the findings of this study still exist.

\section{References}

1. Potočnik K. Possibilities to increase economic efficiency of horse breeding sector. In: Proceedings of the $3^{\text {rd }}$ Regional Symposium of Equine Breeding, Reproduction and Health Protection=Trece regionalno savetovanje Uzgoj, reprodukcija i zdravstvena zaštita konja, Novi Sad. Beograd : Fakultet veterinarske medicine Univerziteta, 2012: 1-11.

2. Stuparu AA, Strugariu CE, Oroian T. Pharmaceuticals and dietary supplements extracted from mare's milk. Bull Univ Agric Sci Vet Med Cluj-Napoca Anim Sci Biotechnol 2016; 73: 1-10. doi 10.15835/buasuvmcn-asb: 11429

3. Polidori P, Vincenzetti S. Use of donkey milk in children with cow's milk protein allergy. Foods 2013; 2(2): 151-9. http://dx.doi.org/10.3390/ foods 2020151

4. Centoducati P, Maggiolino A, De Palo P, Ta- teo A. Application of Wood's model to lactation curve of Italian Draft horse mares. J Dairy Sci 2012; 95: 5770-5. https://dx.doi.org/10.3168/ jds.2012-5513

5. Jastrzębska E, Wadas E, Daszkiewicz T, Pietrzak-Fiećko R. Nutritional value and healthpromoting properties of mare's milk: a review. Czech J Anim Sci 2017; 62: 511-8. https://doi. org/10.17221/61/2016-CJAS

6. Temuujin J, Senna M, Jadambaa TS, Burmaa D, Erdenechimeg S, Amarsanaa J. Characterization of nanoporous materials prepared from mont-morillonite clay and its application to the decolorization of mare's milk oil. J Porous Mater 2006; 13: 49-53. doi 10.1007/s10934-0065489-Z

7. Pikul J, Wójtowski J. Fat and cholesterol content and fatty acid composition of mares' colostrums and milk during five lactation months. Livest Sci 2008; 113: 285-90.

8. Markiewicz-Kęszycka M, Wójtowski J, Kuczyńska B, et al. Chemical composition and whey protein fraction of late lactation mares' milk. Int Dairy J 2013; 31: 62-4.

9. Caroprese M, Albenzio M, Marino R, Muscio A, Zezza T, Sevi A. Behavior, milk yield, and milk composition of machine- and hand-milked Murgese mares. J Dairy Sci 2007; 90: 2773-7.

10. Pieszka M, Łuszczyński J, Szeptalin A. Comparison of mare's milk composition of different breeds. Nauka Przyr Technol 2011; 5: e112 (1-5). https://www.npt.up-poznan.net/pub/ art_5_112.pdf

11. Minjigdorj N, Baldorj O, Austb D. Chemical composition of Mongolian mare milk. Acta Agric Scand 2012; 62: 66-72. http://dx.doi.org/10.108 0/09064702.2012.720999

12. INRA-HN-IE. Guide pratique de l'estimation de l'état corporel chez le cheval de selle et de sport. Paris: Institut de l'Elevage, 1997: 40.

13. ISO-IDF. Milk and liquid milk products - Guidelines for the application of mid-infrared spectrometry (Determination of fat, protein and lactose). International Standard ISO 9622. Brussels : International Dairy Federation, 2013.

14. ISO-IDF. Quantitative determination of bacteriological quality. International Standard ISO 21187. Brussels : International Dairy Federation, 2004.

15. ISO-IDF. Milk-Enumeration of somatic cells-Part 2: Guidance on the operation of Flouroopto-electronic counters. International Standard 
ISO 13366-2. Brussels : International Dairy Federation, 2006.

16. SAS 9.2. SAS/STAT User's guide. Cary, North Caroline : SAS Institute, 2008.

17. Doreau M, Martin-Rosset W. Animals that produce dairy foods - horse. In: Fuquay JW, Fox PF, McSweeney PLH, eds. Encyclopedia of dairy sciences. $2^{\text {nd }}$ ed. San Diego, USA : Academic Press, 2011: 358-64.

18. Salimei E. Animals that produce dairy foods. Donkey. In: Fuquay JW, Fox PF, McSweeney PLH, eds. Encyclopedia of dairy sciences. $2^{\text {nd }}$ ed. San Diego, USA : Academic Press, 2011: 365-73.

19. Gibbs PG, Potter GD, Blake RW, McMullan WC. Milk production of Quarter horse mares during 150 days of lactation. J Anim Sci 1982; 54 : 496-9.

20. Doreau M, Boulot S. Recent knowledge on mare milk production: a review. Livest Prod Sci 1989; 22: 213-35.

21. Santos AS, Silvestre AM. A study of Lusitano mare lactation curve with Wood's model. J Dairy Sci 2008; 91: 760-6.

22. Oftedal OT, Hintz, HF, Schryver HF. Lactation in the horse: milk composition and intake by foals. J Nutr 1983; 113: 2096-106.

23. Smolders EAA, Veen NE, Polanem A. Composition of horse milk during the suckling period. Livest Prod Sci 1990; 25: 163-71.

24. Skrzypek R, Wójtowski J, Fahr RD. Hygienic quality of cow bulk tank milk depending on the method of udder preparation for milking. Arch Tierzucht 2003; 46: 405-11.

25. Steppa R, Wójtowski J, Bielińska S, Kęszycka M. Effect of transferrin and haemoglobin polymorphism on hygienic quality of milk in sheep. Züchtungskunde 2009; 81: 125-32.

26. Strzałkowska N, Józwik A, Bagnicka E, et al. Chemical composition, physical traits and fatty acid profile of goat milk as related to the stage of lactation. Anim Sci Pap Rep 2009; 27: 311-20. http://archiwum.ighz.edu.pl/files/objects $/ 7512 / 66 /$ str311-320.pdf

27. Čagalj M, Brezovečki A, Mikulec N, Antunac N. Composition and properties of mare's Croatian coldblood horse breed. Mljekarsvo 2014; 64: 3-11. https://hrcak.srce.hr/117064

28. Doreau M, Boulot S, Martin-Rosset W, Dubroeucq H. Milking lactating mares using oxytocin: milk volume and composition. Reprod Nutr Dév 1986; 26: 1-11. https://hal.archivesouvertes.fr/hal-00898368/document
29. Dunlap JC, Loros JJ, DeCoursey PJ. Chronobiology: biological timekeeping. Sunderland: Sinauer Associates, 2004: 382 p.

30. Refinetti R. Circadian physiology. 2nd ed. Boca Raton : CRC Press, 2006: 688 p.

31. Piccione G, Fazio F, Caola G, Refinetti R. Daily rhythmicity in nutrient content of asinine milk. Livest Sci 2008; 116: 323-7. http://dx.doi. org/10.1016/j.livsci.2008.01.012

32. Doreau M, Martuzzi F. Fat content and composition of mare's colostrums and milk. In: Miraglia N, Martin-Rosset W, eds. Nutrition and feeding of the broodmare. Wagenigen : Academy Publishers, 2006: 77-7.

33. Mariani P, Summer A, Martuzzi F, Formaggioni P, Sabbioni A, Lucio Catalano A. Physicochemical properties, gross composition, energy value and nitrogen fractions of Haflinger nursing mare milk throughout 6 lactation months. Anim Res 2001; 50: 415-25.

34. Martuzzi F, Summer A, Formaggioni P, Mariani P. Milk of Italian Saddle and Haflinger nursing mares: physico-chemical characteristics, nitrogen composition and mineral elements at the end of lactation. Italian J Anim Sci 2004; 3: 293-9.

35. Danków R, Wójtowski J, Pikul J, Niżnikowski R, Cais-Sokolińska D. Effect of lactation on the hygiene quality and some milk physicochemical traits of the Wielkopolska mares. Arch Tierzucht 2006; 49: 201-6.

36. Luštrek B, Simčič M, Kaić A, Potočnik K. Report on mare's milk analysis. In: A global perspective on performance recording and animal identification. Proceedings of the $40^{\text {th }}$ ICAR Biennial Session. Puerto Varas, Chile, 2016. ICAR Technical Series 2017; 21: 137-40. https://www. icar.org/wp-content/uploads/2017/05/ICARTechnical-Series-21-Puerto-Varas-2017-Proceedings.pdf

37. Doreau M, Boulot S, Barlet J, Patureau-Mirand P. Yield and composition of milk from lactating mares: effect of lactation stage and individual differences. J Dairy Res 1990; 57: 449-54.

38. Csapó-Kiss Zs, Tefler J, Martin TG, Makray S, Csapó J. Composition of mares' colostrum and milk. Protein content, amino acid composition and contents of macro- and micro-elements. Int Dairy J 1995; 5(4): 403-15. https://doi. org/10.1016/0958-6946(94)00014-G 


\title{
KOLIČINA, SESTAVA IN HIGIENSKA KAKOVOST MLEKA PRIDOBLJENEGA Z RUTINSKO STROJNO MOLŽO LIPICANSKIH KOBIL
}

\author{
A. Kaić, B. Luštrek, M. Simčič, K. Potočnik
}

Povzetek: Pridobili in raziskali smo komercialno količino namolženega mleka kobil lipicanske pasme. Rutinska mehanska molža treh kobil je potekala na raziskovalni ustavnovi, registrirani za prirejo kobiljega mleka. Rezultati so pokazali, da je bila povprečna dnevna količina mleka (KM) 8,24 kg, mleko pa je v povprečju vsebovalo 4,027 g maščobe/kg, 15,064 g beljakovin/kg in $63,218 \mathrm{~g}$ laktoze/kg. Povprečno število somatskih celic v mleku je bilo 6,556 x 103/ml, povprečno skupno število mikroorganizmov $114,689 \times 10^{3} / \mathrm{ml}$, povprečna zmrziščna točka (ZT) mleka pa $-0,505^{\circ} \mathrm{C}$. Rezultati analize variance so pokazali, da se količina beljakovin in laktoze ter število somatskih celic in skupno število mikroorganizmov statistično značilno razlikujejo glede na zaporedno molžo ter med posameznimi kobilami ter da se količina beljakovin, število somatskih celic in skupno število mikroorganizmov v mleku zmanjšuje z napredovanjem laktacije, medtem ko se vsebnost maščob povečuje. Interakcija med zaporedno molžo in kobilo je statistično značilno vplivala le na vsebnost maščob. Gre za prvo raziskavo mleka kobil lipicanske pasme, kar omogoča nadaljno primerjavo med pasmami. Uporaba kobil te slovenske avtohtone pasme konj za komercialno rutinsko prirejo mleka bi predstavljala njeno dodatno gospodarsko vrednost in s tem razlog za ohranitev.

Ključne besede: sestava mleka; količina mleka; stadij laktacije; zaporedna molža; higienska kakovost mleka 